\title{
Menciptakan Suasana Perjumpaan Antar-Agama: Refleksi Filosofis Etika Global Hans Küng
}

\author{
Marz Wera
}

\begin{abstract}
Indonesia faces the problem of differences for many year ago until now. Even though, Pancasila symbolizes the unity but mostly in religious relationship have a cliff between "us" and "them" for many reasons recently. Another problem emerges in area of Religious pluralism, makes the situation more difficult. The reality of religious diversity is isolated by misleading and shallow interpretations. The space for dialogue is insulated by religious formalism and theological claims of truth. The dialogue of agreement, both inclusivism and pluralism, has not been able to knit religious plurality. Traditions, symbols, rituals, ethical dimensions and universal core in religious dialogue as a precondition do not find space. In this context, the author is trying to offer the idea of "Global Ethics" by Hans Küng as a new understanding of religious dialogue.
\end{abstract}

Keywords: Pancasila, global ethics, inclusivism, pluralism, ethical dimensions, dialogue

\section{Pendahuluan}

Jika kita memperhatikan ketidakharmonisan kehidupan beragama di Indonesia akhirakhir ini, maka akan memunculkan sebuah pertanyaan reflektif yaitu: sebenarnya, apa yang salah dengan hidup beragama selama ini? Hal ini menjadi pernyataan subtil karena sebenarnya "kami" dan "mereka" sama-sama muncul dalam ruang publik di Indonesia, negara yang berpedoman pada Pancasila. Padahal Pancasila lahir sebagai simpul perekat "kita" dan "mereka" baik dalam suku, agama, ras, golongan, serta berbagai perbedaan yang ada. Paling subtil, karena "kita" dan "mereka" dalam hidup beragama mewarnai ruang publik negara Pancasila hari-hari ini. Situasi ini, seperti menantang hidup beragama untuk mampu memberikan jawaban kontekstual tentang bagaimana universalitas kemanusiaan memanggil kita dalam memaknai kehidupan. ${ }^{269}$ Bila ini benar, bahwa hidup keagamaan sekedar klaim pembenaran kelompok dan sekaligus

${ }^{269}$ Haryatmoko, '’Agama: Etika Mengatasi Kekerasan,’' Kompas, 17 April 2000. 
melegitimasi kekuasaan tertentu, maka justru telah menjadikan agama terasing dari peristiwa hidup sehari-hari.

Akankah hidup beragama mampu memberikan jawaban kontekstual atas situasi ini? Kalau tindakan apologetis ${ }^{270}$ bahwa semua agama selalu hadir untuk mendamaikan, lantas kenapa masih ada "kita" dan "mereka" dalam hidup beragama? Di ruang publik bahkan dalam lingkungan rumah ibadah orang dengan mudahnya melakukan tindakan provokasi melalui sentimen agama.

Kondisi ini kerap terjadi pada berbagai lini kehidupan. Katakan saja ketika proses politik berlangsung, politikus menggunakan isu agama demi menjatuhkan lawan politiknya. Perusahaan pun membawa label agama untuk menipu konsumen. Kaum agamawan rajin berkoar menjual kesucian untuk mengisi kekosongan kantongnya. Dengan posisi agama masuk dalam pemenuhan hasrat untuk mengejar kekuasaan dalam ruang apapun (kelompok agama mana saja) adalah tindakan tak menghormati dan bahkan merendahkan martabat agama itu sendiri. Karena ajaran dan nilai-nilai moral yang luhur telah diturunkan harkatnya dan dijadikan alat untuk mendapat kekuasaan yang fana. Dengan kata lain, suatu bonum maximum direndahkan martabatnya menjadi alat bagi suatu minus malum. ${ }^{271}$

Situasi kian pelik dan rumit ketika kelahiran teknologi membuat manusia semakin otonom. Lalu lintas informasi yang tak terbendung dan tidak dicermati dengan benar oleh manusia membuat setiap orang mencari eksistensi diri sesuai dengan individualitasnya. Hal ini berpengaruh juga kepada pemahaman iman keagamaan, karena dunia penafsiran beralih dari ortodoksi ke heterodoksi. Otonomi diri yang mudah terkecoh oleh gelagat zaman yang kompleks sekaligus mudah dijebak oleh tafsiran sesat dan dangkal. Ruang dialog agama akhirnya kian terhimpit oleh kesempitan wawasan yang mudah terkecoh untuk dimanipulasi. ${ }^{272}$

Hal ini terlihat sepanjang tahun 2016, bahkan hingga tahun 2017 ini. Komnas HAM mencatat sepanjang 2016 terdapat 97 kasus intoleransi agama. Fenomena ini justru berbalik dengan penilaian orang bahwa Indonesia selalu menjunjung tinggi nilai-nilai toleransi. Fenomena ini juga menandai tingkat intoleransi agama yang terus meningkat empat tahun terakhir. Komnas HAM mencatat pada tahun 2014 terdapat 74 kasus, tahun

\footnotetext{
${ }^{270}$ Tindakan membela diri sesuai dengan keyakinan.

${ }^{271}$ Ignas Kleden, 'Agama dan Negara,' Kompas, 30 Mei 2017.

${ }^{272}$ Marz Wera, 'Membingkai Ruang Dialog Antar-Agama,'’ Kompas, 21 Oktober 2017.
} 
2015 terdapat 87 kasus, dan 2016 terdapat 97 kasus. Kasus-kasus ini disinyalir akan terus meningkat di tahun 2017. Tahun 2018 mengalami peningkatan padahal baru terjadi hingga pertengahan tahun yakni Juni 2018 berjumlah 109 kasus dalam kebebasan beragama dan keyakinan. ${ }^{273}$

Dari deretan kasus-kasus intoleransi agama di atas, penulis memperhatikan ada empat kasus yang paling mendapat perhatian dan menguras energi berbagai pihak untuk duduk bersama membuka ruang dialog. Bahkan orang beramai-ramai saling menghujat di media sosial. Pertama, kasus pembubaran paksa kegiatan Ibadah bertajuk Kebaktian Kebangunan Rohani (KKR) yang berlangsung di Sabuga ITB Bandung pada penghujung tahun 2016, bertepatan dengan masa menjelang perayaan Natal bagi umat Kristiani. Kedua, adalah kasus tuduhan penistaan agama kepada mantan gubernur DKI Jakarta Basuki Tjahaja Purnama yang bertepatan dengan konteks politik yang sedang berlangsung pada awal tahun 2017, bahkan masih menyimpan dendam bagi sebagian orang hingga hari-hari ini, juga berefek pada demo berjilid-jilid. Ketiga, laporan beberapa lembaga (LSM) terhadap Habib Rizieq yang dinilai menodai ajaran Kristen-Katolik, yang sampai sekarang belum jelas kasusnya bahkan hilang dari perdebatan publik. Keempat, beredarnya video Ustad Abdul Somad yang dinilai menghina simbol Kristen-Katolik barubaru ini, juga menuai banyak kritikan dan laporan dari beberapa LSM. Empat kasus beruntun sejak tahun 2016 ini, harus jadi refleksi bagi bangsa Indonesia yang menganut Pancasila sebagai pedoman hidup berbangsa dan bernegara.

Fenomena bom bunuh diri yang mengganggu kehidupan bangsa Indonesia beberapa tahun belakangan ini, serta sederetan serangan sebelumnya di beberapa tempat. Beberapa negara patut menjadi pelajaran untuk kita seperti di Marawi Philipina yang masih mencekam hingga hari ini. Timur Tengah yang semakin kaotis dan bengis. Di Eropa: Inggris, Perancis, Turki, Belgia dan Jerman terus di ganggu oleh represi brutal terorisme yang susah ditebak keamanannya. Semua itu tentunya menjadi refleksi tersendiri untuk memperlihatkan masih bermasalahnya konsep dialog kita selama ini.

Dalam negara hukum modern, yang religius dipisahkan dari yang moral, maka kesalehan religius adalah perkara privat yang tak perlu dibawa ke ruang publik. Mendesakkan konsep partikular tentang perintah Tuhan kepada institusi-institusi publik dihitung sebagai politik sektarian yang dapat mengancam kemajemukan. Namun, sikap

${ }^{273}$ Bdk. Laporan Setara Institute, 2018. 
mendua akan mengubah kesalehan menjadi kemunafikan. Masalah kesalehan adalah bagaimana yang religius, yaitu yang baik menurut Tuhan, dan yang moral, yaitu yang baik menurut manusia, dapat disatukan sekaligus dalam satu ide. ${ }^{274}$

Pengaruh lainnya adalah ketika kelahiran teknologi yang membuat manusia semakin otonom, lalu lintas informasi tidak dicermati dengan baik, penafsiran beralih dari ortodoksi ke heterodoksi. Orang mudah terjebak oleh tafsiran sesat dan dangkal. Kesempitan wawasan yang mudah terkecoh dengan manipulasi. Etika komunikasi tak berdaya menghadapi maraknya ujaran kebencian di media. "Kekerasan fisik, pornografi, kekerasan virtual, dan kekerasan simbolik merajalela tanpa ada struktur kuat yang melawannya. Kekuatan moral seperti dibuat tak berdaya. Agama cenderung tergoda untuk mengusulkan pemecahan represif."275

Dalam tulisan ini, penulis akan merefleksikan fenomena di atas dengan gagasan salah satu tokoh inspiratif yang juga seorang teolog dalam konteks dialog lintas-agama. Konsep dan gagasan tokoh ini, patut untuk dipelajari sebagai lokus untuk memahami lebih dalam soal keunikan dan kekhasan masing-masing agama yang harus di perhatikan sekaligus tidak boleh diabaikan.

Gagasannya menurut penulis sangat relevan untuk fenomena hidup beragama saat ini yang mengantarkan kita pada pemaknaan terdalam ke-universal-an sebagai simpul bersama serta tumpuan identitas yang harus dipertahankan tanpa harus mengabaikan yang lain. Perlu untuk menyakini kekhasan dan keunikan kita tanpa harus mengabaikan yang lain; sebaliknya ada apresiasi dan saling mengakui sebagai keindahan hakiki yang hadir untuk saling menghiasi belantara keberagaman nusantara. ${ }^{276}$ Sang teolog penggagas etika global tersebut adalah Hans Küng.

\section{Masa Depan Pluralisme Agama}

Buku Theology of the Third Millennium (1988) adalah jejak awal gagasan Hans Küng yang secara mendalam menggambarkan bahwa periode ini, khususnya di tahun 1988 sampai 2000 sebagai transisi dari era modern ke era postmodern. Pada era inilah, baginya sebagai masa di mana agama-agama sedang mengalami semacam krisis kredibilitas. Melalui buku tersebut Küng mencari jalan keluar bagi agama dalam

\footnotetext{
${ }^{274}$ F Budi Hadirman, "Kesalehan dan Kekerasan,” Kompas, 6 Januari 2017.

${ }^{275}$ Haryatmoko, 'Kekerasan Dalam Media,'” Kompas, 3 Juli 2008.

${ }^{276}$ Marz Wera, '’Membingkai Ruang Dialog Antar-Agama,'’ Kompas 21 Oktober 2017.
} 
melakukan fungsi kritis bagi kehidupan manusia baik secara individu maupun bersama. ${ }^{277}$

Küng mengonfirmasi bahwa pluralitas dalam pluralisme agama adalah realitas hidup manusia yang sudah jelas-jelas terbukti. Proses pluralisasi tersebut kemudian secara dinamis seiring sejalan dengan modernitas. Dalam konteks itu, pola pikir umat beragama mulai mengalami pengaruh postmodern.

Kemajuan teknologi mengalienasi manusia dari nilai-nilai kemanusiaan universal dan sikap netral dalam memperlakukan sesama warga negara. Urusan internal agama direduksi untuk diperdebatkan dengan isu miring di ruang publik. Kenyataan yang kompleks ini membuka refleksi bagi para pemikir keagamaan untuk menilai kembali doktrin-doktrin teologisnya. Hidup beragama terlibat dalam dialog yang intens, namun upaya ini tidak bisa menghapuskan kesalahpahaman antara sesama pemeluk agama dalam memandang secara serius identitas agama seseorang. ${ }^{278}$

Gerardette Phillips memaparkan tiga bahaya dalam pluralisme. Pertama, cacat secara metodologis. Karena dilandasi sebuah upaya bersama untuk mencari apa yang umum bagi semua agama, maka para pluralis justru mengabaikan secara serius unsurunsur penting serta keunikan agama-agama. Contohnya konsep Trinitas dalam Katolik, Nubuat Nabi Muhammad dalam Islam, Empat Kesunyatan Mulia dalam Buddha, Kristen dengan tradisinya, tradisi Nyepi dalam umat Hindu, serta jalan spiritual dalam umat Konghucu dengan tradisi Imleknya. Kedua, bermasalah secara moral yang mengarah pada tendensi pluralisme intelektual keagamaan secara umum. Tentunya bermasalah, karena semua tradisi agama merupakan cara manusia merespons kepada Tuhan dengan berbagai kekhasan dan perbedaan yang cukup spesifik. Ketiga, pluralisme secara logis mustahil, sebab orang akan dengan gampangnya merelatifkan bahwa semua gagasan agama adalah sama sesuai dengan pemahamannya sendiri. Ini akan cenderung memaksakan orang lain yang berbeda untuk mempercayai begitu saja. ${ }^{279}$

Pluralisme adalah wujud sejati kebhinekaan dalam ikatan keadaban. ${ }^{280}$ Dengan demikian penting bagi umat beragama untuk menyadari bahwa perkembangan teologi di masa yang akan datang, dan agama manapun meyakini bahwa merupakan hasil langsung

\footnotetext{
${ }^{277}$ Hans Küng, Theology for The Third Millenium - An Ecumenical View, (New York: Doubleday, 1988): Xv

${ }^{278}$ Gerardette Phillips, Melampui Pluralisme (Malang: MADANI, 2016), iii

${ }^{279}$ Ibid. hlm. 231-144

${ }^{280}$ Nurcholish Madjid, Genuine engagement of diversities within the bonds of civility, dalam Republika, 10 Augustus 1999. Lihat juga, Madjid 2002a: 172
} 
dari dialog yang serius dengan agama-agama lain. ${ }^{281}$ Era keterbukaan mendorong bahkan membuka ruang yang sangat luas bagi pemeluk agama-agama untuk bisa menjadikan dialog sebagai sikap dasar dalam mengikat sebuah kerjasama antaragama.

Melalui dialog, orang saling berbagi pengalaman iman antaragama. Membuka kesempatan untuk saling mendengarkan kebijaksanaan dan persoalan-persoalan dari agama lain. ${ }^{282}$ Dengan dialog sesama pemeluk agama saling mengakui kehadiran kehendak Allah yang menyelamatkan dalam ajaran dan praktek dari agama-agama yang bersangkutan. ${ }^{283}$ Para pemikir filsafat dan teologi merumuskan bahwa pemahaman pluralisme agama terjadi jika pemeluk dari setiap agama menyingkirkan pandangannya sendiri dan berusaha menerima pihak lain dan "melihat" alam semesta agamanya melalui konsep-konsep pihak lain. ${ }^{284}$ Ini sebagai reaksi positif atas dasar universalitas nilai serta pengakuan timbal balik antaragama untuk saling menerima.

Namun yang terjadi akhir-akhir ini, dialog beragama justru terkurung oleh persaingan mencari eksistensi diri ke dalam percaturan kekuasaan. Ada narasi-narasi kecil dengan alibi atas nama kebebasan mengemukakan pendapat di muka umum. Polapola semacam ini akan membawa kita pada pola dialog beragama di masa kolonial. Ketika dialog dikondisikan oleh pemerintah kolonial, hal tersebut akan mewarnai gerakangerakan misioner untuk bisa merebut pengikut yang banyak. Pemegang peran justru adalah lembaga-lembaga, yang secara khusus memegang prinsip doktrin iman agama masing-masing. ${ }^{285}$

Konteks ini sangat berbahaya karena pluralisme agama justru diwarnai oleh maraknya gerakan samar, ideologi politik dan ideologi agama. Pola dialog yang dimaksud untuk menghindari konflik, sehingga yang terlibat dialog hanyalah tokoh-tokoh agama, pemerintahan, lembaga-lembaga masyarakat, hanya tataran kaum elit. Mengondisikan demi stabilitas sementara waktu akan tetapipada kesempatan lain diam-diam melakukan gerakan samar demi menguasai dan mendominasi yang lain.

Pada konteks yang lain masih ada hambatan dalam aspek teologis. Misalnya dalam Kristen, evangelisasi merupakan suatu dialog, namun menjadi persoalan ketika evangelisasi identik dengan pengajaran pada semangat pertobatan orang lain. Ini

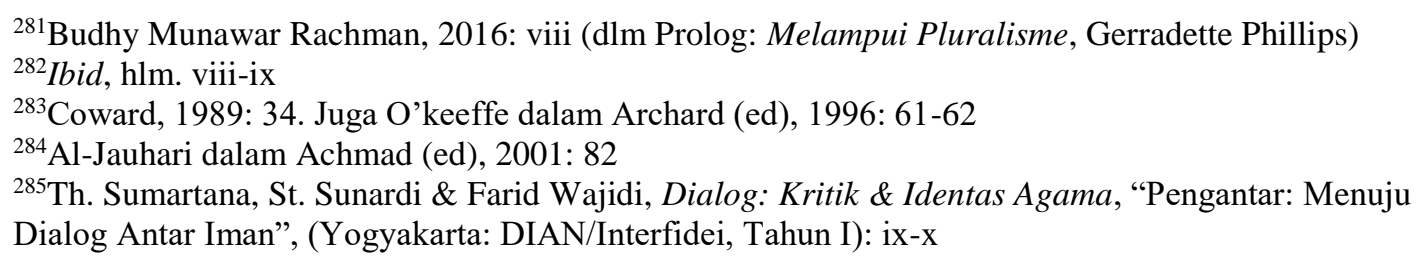


menjadi domain yang harus benar-benar diperhatikan oleh para tokoh agama dalam memberikan pemahaman baru dengan tafsiran baru ke umat agar bisa menerima dengan baik dan sederhana sehingga umat dengan sendirinya punya inisiatif dalam menjalankan dialog. ${ }^{286}$

Tak ketinggalan pula maraknya isu-isu yang dimainkan oleh tokoh-tokoh berpengaruh, seperti isu Kristenisasi. Ini memunculkan perdebatan yang menakutnakuti pemeluk agama lain. Keragaman narasi internal dalam agama mengemuka sebagai dalil untuk mematikan ruang gerak agama lain. Sementara dari arah sebaliknya, ketika ada kaum inklusif agama yang sama membela agama lain dalam dalil universalitas nilai, justru dituduh sebagai antek Kristen, Zionisme, Ateis, dan lain-lain.

Seyogyanya pluralisme agama adalah pengalaman akan kesadaran dari dalam diri seseorang sesuai dengan iman agamanya menuju ke universalitas agama-agama. Pengalaman ini hadir meleburkan diri ke dalam situasi sejarah peradaban, dengan segala sosio-kultural yang beragam. Dari konteks inilah vitalitas agama ditantang untuk mampu mengantarkan para pemeluknya ke pengalaman liberatif sebagai nilai inti agama dalam memanifestasikan ke peristiwa hidup sehari-hari.

Bahwa agama tanpa spiritualitas yang mendalam serta moralitas yang luhur, agama justru bisa jadi sumber bencana, sumber datangnya kiamat kemanusiaan. Tanpa cinta, agama bisa jadi sumber sikap radikal dan agresif. Sebagaimana kita lihat dalam beberapa tahun belakangan ini, agama telah disalahpahami dan disalahpraktikkan sehingga jadi pemicu kekerasan dan peperangan. ${ }^{287}$ Jika membiarkannya maka masa depan kehidupan beragama semakin sulit.

\section{Membuka Ruang Dialog Pada Pluralitas Agama}

Sesungguhnya pluralisme agama itu soal bagaimana pemahaman para penganut akan ajaran, keyakinan masing-masing dari sisi agamanya pada kebenaran teologis sebagai kekhasan internal agama-agama yang perlu dihargai. Pada tingkat penghayatan lebih dalam, semua insan perlu memahami bahwa semua agama bukan hanya peninggalan masa lalu dan bukan hanya sekedar perjalanan peradaban dengan segala aspek teoritisnya, tetapi bagian dari kontruksi realitas yang memberikan pendasaran nilai-nilai hakiki yang sudah menjelma dalam sejarah peristiwa hidup manusia.

\footnotetext{
${ }^{286}$ Marz Wera, 'Hakekat Kemanusiaan Adalah Bersahabat,' Kompas, 25 Februari 2016

${ }^{287}$ Haidar Bagir, “Cinta Sebagai Asas Agama,” Kompas, 18 Juli 2016
} 
Raimundo Panikkar merumuskan bahwa dalam melakukan dialog dan mengembangkan kesadaran inklusif, sedikitnya akan menyentuh dua hal. Pertama, menghidupkan suatu kesadaran tentang pokok iman orang lain. Kedua, mengarahkan kepada kerjasama untuk memecahkan persoalan kemanusiaan bersama di masyarakat. $^{288}$ Pernyataan ini sejalan dengan tesis bahwa pluralitas agama sudah menjelma dan ada sejak zaman para nabi yang merupakan tugas kemanusiaan yang universal.

Orang jangan hanya fokus pada dimensi formal agama-agama, melainkan bagaimana agama hadir dalam menangani realitas sosial. Hidup sehari-hari merupakan keaslian bagi manusia untuk menampilkan wajah agama yang otentik. ${ }^{289}$ Wujudnya menghadirkan pluralitas nilai untuk sebaik mungkin menjalin komunikasi yang intens tentang ajaran-ajaran iman agama masing-masing ke wilayah dialog agama. Melalui konsep pluralitas ini kita saling belajar untuk memahami, sehingga setiap waktu selalu ada kesempatan untuk berdialog mewujudkan nilai-nilai kehidupan bersama. "implikasi kesadaran ini menyangkut kesediaan untuk menyesuaikan diri di bawah cahaya kesadaran ketuhanan."290

Kesadaran ini bersumber pada sifat ilahiah, kondisi ketergantungan manusia dalam meyakini dan memutlakkan kebenaran akan keyakinannya pada keilahian. Manusia punya keterbatasan dalam menjangkau dan menangkap kemutlakan sebagai doktrin kebenaran. Oleh karena itu perlu memperhatikan keyakinan yang lain, memilih jalan yang berbeda tetapi menuju tujuan yang sama.

Kesalahan utama penyebab permasalahan dewasa ini adalah cara manusia memahami dan memanifestasikannya. Konflik beragama muncul karena orang sering membandingkan cara dirinya beragama dengan orang lain, yang sebenarnya bukan pilihannya secara bebas dan akal sehat. Karena hakekat orang beragama adalah mengikuti warisan lingkungan hidupnya mulai dari keluarga hingga masyarakat. Bila terdapat kesadaran dan pemahaman beragama yang sepenuhnya, akan keterbatasan dan ketidakmutlakan manusia dalam mengontrol iman beragama. ${ }^{291}$ Kesadaran beragama

\footnotetext{
${ }^{288}$ Raimondo Panikkar, 1981: 58-60

${ }^{289}$ Antonius Subianto Bunyamin, 'Humanisme Bagi Otentisitas Diri,' Simposium Filsafat Universitas Katolik Parahyangan, Bandung 29 Mei-2 Juni 2014

${ }^{290}$ Budhy Munawar Rachman, 'Kesatuan Trasendental dalam Agama: Perspektif Islam tentang Kesamaan Agama-Agama,' dalam Dialog: Kritik \& Identitas Agama (Yogyakarta: DIAN/Interfidei, Tahun I 1993) 123

${ }^{291}$ Djohan Effendi, ' 'Dialog Antar Agama: Bisakah Melahirkan Teologi Kerukunan' Prisma, 5, (Juni 1978): 16-17
} 
yang dimaksud adalah bahwa semua agama selalu mengusung ajaran kebenaran yang tak pernah secara utuh dan sempurna ditangkap oleh manusia, yang secara hakikat sebagai keutuhan ciptaan-Nya. Manusia terbatas dalam memahami segala sesuatu.

\section{Konsep “Etika Global” Hans Küng}

Konsep Etika Global dimulai dengan deklarasi, 'Declaration Toward a Global Ethic." Sekaligus mengawali dua karya yaitu Justifikasi ${ }^{292}$ dan Etika Global. ${ }^{293}$ Kemudian pada tahun 1990 Küng merumuskan hasil penelitiannya tentang standar etis fundamental agama dengan sebuah buku programatik berjudul Global Responsibility: In Search of a New World Ethic. Buku ini sebagai langkah awal menuju deklarasi Etika Gobal melalui persetujuan Parlemen Dewan Agama-Agama Dunia di Chicago pada tahun $1993 .^{294}$

Kedudukan Hans Küng sebagai seorang pengajar sempat menimbulkan kontroversi, banyak peringatan dan surat-surat resmi dari uskup-uskup Jerman dikirim ke Tübingen tempat ia mengajar teologi Katolik. Hingga pada 18 Desember 1979 pihak Roma mencabut missio canonica (hak resmi Vatikan) untuk mengajar doktrin resmi Gereja Katolik. Alasannya bahwa ajaran Küng dinilai tidak sesuai lagi dengan semangat ajaran Katolik. ${ }^{295}$ Karena gagasan Küng yang meragukan dogma tentang infalibilitas ${ }^{296}$ di dalam gereja; ia cenderung mengakui adanya kemungkinan salah dari pernyataanpernyataan doktrinal yang dikeluarkan Gereja. ${ }^{297}$

Meskipun demikian teolog kelahiran Swiss ini masih mengakui dirinya sebagai seorang teolog dan anggota Gereja Katolik. Hubungan dilematis ini tergambar dalam

\footnotetext{
${ }^{292}$ Nilai minimum yang dibutuhkan umum, standar dan sikap dasar dalam kehidupan umat beragama. ${ }^{293}$ Deklarasi ini memiliki nama Declaration Toward a Global Ethic bukan Etika Global. Etika berarti suatu sikap moral dasar manusiawi, sedangkan etika menunjuk pada dimensi filosofis dan teologi dari sikap, nilai-nilai dan norma-norma moral.

${ }^{294}$ Gerardette Phillips, Melampui Pluralisme, (Malang: Madani, 2016): Hal. 85

${ }^{295}$ St Sunardi, Dialog: Cara Baru Beragama (Sumbangan Hans Küng bagi dialog antar agama), (Yogyakarta: DIAN/Interfidei, Tahun I 1993): 59

${ }^{296}$ Infalibilitas kepausan adalah dogma yang menyatakan bahwa, dengan kuasa Roh Kudus, Sri Paus dilindungi dari (bahkan) kemungkinan membuat kesalahan ketika ia secara resmi menyatakan atau mengumumkan kepada Gereja mengenai sebuah ajaran dasar tentang iman atau moralitas seperti yang terkandung di Wahyu Tuhan

${ }^{297}$ Ibidem, gugatan Küng tentang dogma infalibilitas dituangkan dalam bukunya Infallible?, (Collins, London, 1971): 11 .
} 
semboyan, "Gereja Katolik, yes! Inquisisi298 Roma, no!"299 Sikap dan pendiriannya yang tegas sudah tampak sejak meniti karirnya sebagai seorang teolog dengan spesialisasi teologi dogmatik ${ }^{300}$ dan ekumenis. ${ }^{301}$ Tahun 1962 masih terhitung sebagai seorang teolog muda, Küng mendapat kepercayaan dari mendiang Paus Yohannes XXIII untuk tergabung dalam kelompok ahli Konsili Vatikan II. Secara spesifik mengemban tugas memberikan kuliah kepada para uskup tentang reform dalam bidang liturgi dan doktrin, persoalan ekumenis, serta hubungan antara kepausan dan para uskup. ${ }^{302}$

Pada paruh tahun 1988 Küng menulis buku dengan judul Theology for Third Millenium. Ia melukiskan periode masa itu sebagai masa transisi dari era modern ke postmodern, ${ }^{303}$ dimana agama mengalami krisis kredibilitas. Sehingga perlu rumusan baru bagi agama untuk menjalankan fungsi kritis bagi kehidupan manusia baik secara individual maupun bersama, agar bisa menemukan kembali kredibilitas dan vitalitasnya. ${ }^{304}$

Ciri-ciri era ini adalah komitmen yang terarah pada nilai kemanusiaan dan lingkungan hidup. Nilai-nilai diangkat lagi di atas nilai-nilai artifisial yang berdasarkan pada dewa-dewa palsu dari modernisme. Di tengah keprihatinan manusia untuk melindungi kemanusiaan inilah peran agama sungguh dinantikan. ${ }^{305}$ Dari sinilah hubungan antara agama dan manusia maupun antaragama mengalami pembaharuan

\footnotetext{
${ }^{298}$ Istilah yang secara luas digunakan untuk menyebut pengadilan terhadap bidaah yang didakwa bertentangan dengan Gereja Katolik Roma

${ }^{299}$ Hans Küng, "Why I Remain a Catholic," dalam Hans Küng \& Edward Schillebeekx, Consensus in Theology? A dialogue with Hans Küng and Edward Schillebeekx, (edited by Leonard Swidler), (Westminster: Philadelphia, 1980): 165

${ }^{300}$ Refleksi kritis sistematis atas iman Katolik sekaligus merenungkan kebenaran pokok-pokok iman katolik dalam terang wahyu ilahi, yaitu Tradisi dan Kitab Suci.

${ }^{301}$ Berasal dari bahasa Yunani oikos (=rumah) dan menein (=tinggal), sehingga oikoumene berarti "rumah yang ditinggali" atau "dunia yang didiami". Dalam pengertiannya yang paling luas, ekumenisme berarti inisiatif keagamaan menuju keesaan di seluruh dunia.

${ }^{302}$ Hermann Haering \& Karl-Josef Kuschel (eds.) with Margaret Gentner, Hans Küng: His work and his way, (Fount: London, 1979): 18.1

${ }^{303}$ Gerakan abad akhir ke-20 dalam seni, arsitektur, dan kritik, yang melanjutkan modernisme. Termasuk dalam pascamodernisme adalah interpretasi skeptis terhadap budaya, sastra, seni, filsafat, sejarah, ekonomi, arsitektur, fiksi, dan kritik sastra. Pascamodernisme sering dikaitkan dengan dekonstruksi dan pascastrukturalisme karena penggunaannya sebagai istilah mendapatkan popularitas yang signifikan pada waktu yang sama dengan pascastrukturalisme, yaitu dalam abad kedua puluh.

${ }^{304}$ St Sunardi, Dialog: Cara Baru Beragama (Sumbangan Hans Küng bagi dialog antar agama), (Yogyakarta: DIAN/Interfidei, Tahun I 1993): 62.

${ }^{305}$ Ibid, hlm. 63
} 
secara dewasa, Küng melihat bukan hanya tantangan baru melainkan kesempatan baru untuk meninjau kembali. ${ }^{306}$

Gagasan ini diawali oleh kebuntuan atas konsep dan gagasan para filsuf ateistik modern seperti Feuerbach, Marx dan Nietzsche yang secara sistematis dan ilmiah ingin meniadakan agama sekaligus mengabaikan kodrat manusia. ${ }^{307}$ Para filsuf ini lupa bahwa kebebasan manusia akan berujung pada proses perbudakan bahkan sampai pada gejala dehumanisasi ${ }^{308}$ tanpa batas.

Posisi teologis Küng adalah agama tidak bertentangan dengan kemanusiaan namun menyempurnakan kemanusiaan. ${ }^{309}$ Gagasan ini mendorong Küng berkomitmen dengan menulis buku-buku secara masif guna menjawab isu postmodern. Di antaranya: Does God Exist? (1980: ed. Jerman 1978), Eternal Life? (1984: ed. 1978) dan yang fenomenal adalah ringkasan iman Kristen dengan istilah Summa dalam judul On Being a Christian (1977: ed. 1978).

Posisi teologis Küng sebagian besar terangkum dalam buku Justification: Doktrine of Karl Barth and Catholic Reflection. Ia melihat implikasi sosial dari agama. Agama harus mengedepankan pengalaman dan interaksi hidup bersama sesuai konteks budaya dan tradisi masyarakat dimana mereka hidup dan bertumbuh. Agama dalam diri manusia adalah Tuhan bagi seluruh umat manusia. Sebagai penyingkapan dalam mengungkapkan dimensi universal agama-agama dengan kesamaan yang dimiliki ketimbang mencari-cari apa yang memisahkan.

Teologi agama-agama harus menjadi teologi yang hidup dan mampu berdialog secara bertanggung jawab. Agama-agama harus berteologi dengan niat menuju perubahan universal melampui batas-batas pengakuan identitas manusia. Secara lebih rinci Küng menyatakan bahwa sebuah teologi yang bertanggung jawab untuk rekonsiliasi, memperluas konsep ekumenisme agama-agama, dan tentu saja seluruh bumi yang dihuni dan dengan demikian bekerja untuk perdamaian baik secara teoritis maupun praktis. 310

\footnotetext{
${ }^{306}$ Thomas Quinn \& Stefanie Heiss, interview Hans Küng dalam Lutfhansa Bordbuch, 5/91, 29-34. Dalam St Sunardi, Dialog: Cara Baru Beragama (Sumbangan Hans Küng bagi dialog antar agama), (Yogyakarta: DIAN/Interfidei, Tahun I 1993): 63

${ }^{307}$ Hans Küng, Theology for the Third Millenium, 1988: 6.

${ }^{308}$ Suatu proses yang menjadikan manusia tidak sesuai dengan kodratnya sebagai manusia.

${ }^{309}$ St Sunardi, Dialog: Cara Baru Beragama (Sumbangan Hans Küng bagi dialog antar agama), (Yogyakarta: DIAN/Interfidei, Tahun I 1993): 64

${ }^{310}$ Hans Küng, My Struggle for Freedom Memoirs-1. (J. Bowden. Trans), (USA: Wm. B. Eerdmans Company, 2003): 148
} 
Perlu ada satu titik kesamaan sebagai ikatan bersama menuju perdamaian. Karena "tidak ada keberlangsungan hidup tanpa sebuah etika dunia. Tidak ada perdamaian dunia tanpa perdamaian di antara agama-agama. Tidak ada perdamaian antara agama-agama tanpa dialog di antara agama-agama."311 Ia meyakini perlunya kerjasama secara tanggung jawab dan terbuka untuk saling merangkul melampui identitas agama-agama.

Etika globalnya memuat empat prinsip dasar. Pertama, tidak ada tatanan global baru tanpa suatu etika global. Tanggung jawab manusia atas tatanan global yang lebih baik pada keterlibatan dan semangat dasar keyakinan etis menuju universalitas kemanusiaan. Kedua, sebuah tuntutan fundamental: setiap manusia harus diperlakukan secara manusiawi. Apa yang Anda sendiri tidak inginkan, jangan lakukan pada orang lain, atau apa pun yang Anda ingin orang lakukan untuk Anda, lakukan juga untuk mereka. Ketiga, empat pedoman, yaitu: non-kekerasan dan menghormati kehidupan, solidaritas dan tatanan ekonomi yang adil, toleransi dan hidup sejati, hak-hak yang sama dan kemitraan di antara laki-laki dan perempuan. Keempat, suatu transformasi kesadaran. Bahwa ada kesadaran baru menuju rasionalitas masyarakat yang plural dalam beragama. ${ }^{312}$

Menurutnya, suatu agama dikatakan benar dan baik bila dan sejauh agama itu manusiawi, tidak menghilangkan dan menghancurkan kemanusiaan, tetapi melindungi dan memajukannya. ${ }^{313}$ Dalam realitas hidup, manusia akan selalu menemukan setiap perbedaan atas cara berperilaku dan bersikap, penghargaan terhadap sesama, dan rasa saling menghormati. Seseorang dikatakan Katolik, berarti orang tersebut menjadi manusia secara Katolik, maksudnya agama dalam konteks ini adalah konkret, hakekat untuk memahami proses menjadinya manusia. Sehingga kita bisa pahami bahwa kemanusiaan itu secara alamiah bermula dari dimensi religius, sekaligus agama bermula dari dimensi manusiawi. ${ }^{314}$

Usaha Küng jelas dalam konteks gagasan dialog beragama yakni bagaimana orang dalam memahami agama bukan secara teoritis, tetapi hidup dan menjelma dalam peristiwa hidup sehari-hari. Menurutnya, realitas hidup itu soal sikap yang mempercayai

\footnotetext{
${ }^{311}$ Hans Küng, Global Responbility In Search of a New World Ethic, (New York: The Crossroad Publishing Company, 1991): xv

${ }^{312}$ Hans Küng \& Karl-Josef Kuschel, A Global Ethic The Declaration of the Parliament of World Religions, (USA: Continnum Publishing Company, 1993) lihat juga Gerardette Phillips, Melampui Pluralisme, (Malang: Madani, 2016): 89-92

${ }^{313}$ Hans Küng, Global Responbility In Search of a New World Ethic, (New York: The Crossroad Publishing Company, 1991): 244

${ }^{314}$ Hans Küng, 'Introduction: The debate on the word Religion,' dalam Concilium, xii
} 
hidup, pendekatan dan ruang hidup bersama, cara memaknai hidup, bagaimana menjalin relasi sekaligus perjumpaan dengan sesama. Adanya kesadaran dalam proses bertumbuh dan komitmen hidup baik bersama, memberi makna bagi sesama, patuh pada nilai dan norma hidup bersama dalam masyarakat.

\section{Simpul Etika Global}

Dalam konteks diskursus pluralisme: memahami ajaran, keyakinan, dan klaim kebenaran teologis adalah kekhasan internal yang perlu dihargai oleh sesama. Lebih dari itu, semua agama bukan hanya sistem peninggalan sejarah masa lalu, bukan juga sekedar peradaban dengan segala aspek teroritisnya, tetapi realitas yang sudah menjelma dalam peradaban manusia.

Maka menurut Küng, melalui dokumen Justifikasinya berpendapat secara hakekat manusia itu individu namun dalam kenyataan hidupnya, ia tidak dapat menghindar dari kehidupan bersama orang lain untuk saling menilai dan mengakui sebagai implikasi sosio-etis hidup sosialnya. Sang teolog tersebut menekankan pada pengalaman dan interaksi hidup, tradisi naratif, hermeneutika dan konteks budaya yang hidup. Oleh karenanya, ia mengusulkan perlunya emansipatoris politis tidak hanya sosial etis.

Bagi Küng, Tuhan adalah Tuhan bagi sesama (seluruh) umat manusia, sehingga keselamatan itu diperoleh apabila Tuhan itu hadir dalam masing-masing kita untuk saling berbagi kepada sesama, sebagai ungkapan universalitas yang melintasi batas-batas budaya dan agama. Ia menitikberatkan pada apa yang menyatukan ketimbang apa yang memisahkan. Sehingga perlu bersama mengembangkan suatu nilai yang dapat diterima semua orang.

Küng mengajak kita untuk memahami 'dari dalam,' bagaimana cara agama lain melihat Tuhan dan dunia, baik juga terhadap sesama. Termasuk di dalamnya kemantapan dalam berpolitik, berlaku adil dalam hukum, punya dimensi etis dalam merumuskan pandangan kepada sesama yang berbeda. Etika Global merujuk pada norma etis yang tidak tertulis namun menjadi landasan atau pedoman hidup masyarakat dalam membangun kehidupan bersama diantara keragaman tersebut. Disebut "etika primal"315 dimana pola pembentukan etika universal, nilai-nilai inti bersama dalam tatatan sosial

\footnotetext{
${ }^{315}$ Nilai-nilai dasar yang terbuka untuk semua orang.
} 
secara global yang didasarkan pada ruang dan waktu, konteks peristiwa hidup masyarakat yang dinamis.

Intinya sebagai wahyu Ilahi, perbedaan antara agama tampak dalam cara memanifestasikan kebenaran dan tindakan religius untuk mengungkapkan kuasa Tuhan atas manusia melalui tradisi yang berbeda-beda. Pluralisme agama dalam hidup manusia adalah sebuah fakta peradaban tentang keberadaan manusia dengan berbagai dimensinya, baik: ideologi, tradisi, ritual dan simbol adalah realitas yang sudah jelas-jelas terbukti. Kendati ada perbedaan, baik: bentuk, praktik, budaya, makna itu merupakan kesatuan esensial yang mewujud kedalam diri manusia tentang yang Ilahi. Mereka yang berbeda agama dengan kita hanya terletak pada wajah agama yang lain.

Dengan demikian, menurut tafsir saya "Etika Global" merupakan perumusan ulang seperangkat nilai, moral dan standar etika sebagai konsensus universal yang dapat diterima oleh semua agama. Karena melalui tradisi dalam agama-agama, masing-masing orang dengan iman agamanya akan memahami bentuk dan makna sakral tanpa merusak keabsolutan agamanya juga agama yang lainnya. Inti kesadarannya adalah bahwa semua agama pada tingkat absolut dan kemutlakan adalah sama. Cara manifestasinya saja yang berbeda.

\section{Dialog sebagai Cara Baru Beragama}

Dialog merupakan kepedulian pada sesama baik dari aspek sosiologis maupun aspek teologis.

Dialog bukan hanya sebuah keharusan, melainkan ada penghargaan dan bagaimana cara kita menempatkan "yang lain" dari perspektif "saya," sekaligus menempatkan "saya" dalam perspektif "yang lain."316 Dialog melahirkan sikap simpatik untuk merangkul yang lain. Berhadapan dengan beragamnya umat beragama, kita akan mendengarkan, membiarkan diri disapa oleh iman dan kehidupan mereka. Bersamasama berusaha untuk saling mengerti dan memahami. ${ }^{317}$

Dialog sebagai cara baru beragama, ia beranjak dari pengalaman inti manusia lahir, hidup dan bertumbuh. "Pengalaman inti suatu agama adalah pengalaman liberatif yang melahirkan agama itu dan terus-menerus ditawarkan kepada generasi-generasi

\footnotetext{
${ }^{316}$ Ibid. hlm. 16

${ }^{317}$ J. B. Banawiratma, Bersama Saudara-Saudari Beriman Lain, "Perspektif Gereja Katolik" (Yogyakarta: DIAN/Interfidei, Tahun I 1993): 16
} 
selanjutnya."318 Bahwa hidup beragama menuju masa depan akan terus diceritakan melalui berbagai instrumen dari generasi yang satu ke generasi yang lain. Konteks demikian bisa melalui teks ilmiah, kesempatan setiap orang untuk berpengalaman, tradisi yang hidup di suatu lingkungan, karya sastra lokal, seni dan budaya yang terus bergerak maju, dunia pendidikan yang secara sistematis menjembatani ini, dan lebih dari itu pengalaman iman yang hidup dan tumbuh secara nyata dalam peristiwa hidup seharihari. Vitalitas iman beragama bergantung pada semangat keterlibatan untuk mengantarkan para pemeluknya ke dalam pengalaman inti liberatif. ${ }^{319}$

Dengan situasi yang terjadi seperti demikian, maka secara spontan dan alamiah kesadaran setiap individu akan perlahan-lahan muncul dari pranata "individual" ke kelompok "masyarakat." Kesadaran yang dalam pandangan teolog seperti John Hick dan Knitter adalah adanya pengakuan akan kebenaran dengan cara yang berbeda-beda. Fitzgerald dan Borelli memperjelas bahwa pluralisme agama itu mengacu pada keberagaman agama yang terlibat. Karena perbedaan tradisi khususnya agama dalam masyarakat adalah fakta keberagaman.

Bagaimanapun agama adalah fenomena kemasyarakatan, pandangan hidup yang mengandalkan iman pada dimensi transenden atau Wahyu khusus. ${ }^{320}$ Saling memberikan kesempatan untuk menjelaskan diri sendiri dalam bahasa kita dan siap untuk menjadikan semua ini sebagai syarat-syarat bagi seseorang memahami dirinya dan apa yang dipercayai. ${ }^{321}$

Manusia perlu saling menjaga keberlangsungan hidup bersama di dunia ini melalui dialog dalam keagamaan. Karena sebagai subyek yang bertuhan dan beragama, manusia mendiami bumi, matahari pemberian Tuhan, maka tidaklah seharusnya menghancurkan tata kehidupan karena pilihan keyakinan dan tawaran keselamatan hidup yang melampaui batas dunia. Sebaliknya terjadinya kesesuaian (taufik) antara kehendak Langit dan kreasi manusia di bumi. Tuhan yang diyakini sebagai sumber kasih mesti diwujudkan dalam kehidupan sosial yang diikat dengan tali kasih (silaturahim). Justru sikap keberagamaan hendaknya mendatangkan rahmat bagi semesta. ${ }^{322}$

\footnotetext{
${ }^{318}$ Ibid. hlm. 17

${ }^{319}$ Keterbukaan pada dimensi-dimensi etis bersama secara universal

${ }^{320}$ Ibid. hlm. 19

${ }^{321}$ Gerardette Phillips, Melampui Pluralisme, (Malang: MADANI, 2016): 272

${ }^{322}$ Komaruddin Hidayat, "Fitrah Manusia Ber-Tuhan," Kompas, 27 Juli 2015
} 
Dalam kaitannya dengan kontek Indonesia yang berlandaskan Pancasila, maka penulis merekomendasikan lima gagasan dialog beragama Küng. Pertama, pendidikan agama sebaiknya lebih menekankan pada sosiologi beragama. ${ }^{323}$ Hal ini berkaitan dengan soal pembedaan wilayah teologi beragama dan sosiologi beragama. Dengan konsep ini, anak-anak akan dibiasakan untuk memahami lingkungan sosialnya, soal realitas perjumpaan dengan insan yang berbeda. Karena sosiologi beragama fokus pada bagaimana agama hadir dalam realitas hidup bersama. Ini bisa memakai metode live in melalul kolaborasi dan kerjasama lintas lembaga pendidikan lintas iman yang terintegrasi.

Kedua, dialog kultural. Kekayaan budaya nusantara yang beragam dan estetik bisa menjadi modal karena ada tradisi yang hidup, ada simbol estetik yang berwarna, lalu ada universalitas nilai yang terpatri dalam peradaban kebudayaan yang melekat secara alamiah. Melalui kegiatan festival seni dan budaya yang melibatkan warna keberagaman masyarakat.

Ketiga, pengembangan literasi. Sebagai kesiapan kita untuk menyambut bahkan seiring sejalan dengan gejala teknologi yang kian canggih, bersamaan dengan itu perkembangan rasionalitas orang juga makin hari makin maju maka perlu diperkuat dunia literasi. Budaya baca tulis harus terus dipupuk dan dikondisikan agar masa depan anak cucu kita tidak gagap dengan kompleksitas zaman. Sebab, sebagian besar isu intoleransi belakang ini disebabkan oleh lemahnya literasi, sehingga banyak yang mudah percaya pada berita hoax yang kebenarannya patut dipertanyakan. Pada titik ini kemampuan warga bangsa menjadi lemah. Akibatnya lebih mudah percaya pada berita bohong dan mudah terjebak pada isu publik yang tidak penting untuk di tanggapi.

Keempat, tata kelola ruang publik untuk keterlibatan. Mengajak warga untuk berpartisipasi dalam kegiatan bersama, mendorong keterlibatan warga dalam mengambil setiap kebijakan yang berhubungan dengan hajat hidup umat beragama, bekerja sama lintas golongan, bersama mengembangkan rasa solidaritas sosial dalam dialog agama yang bermakna. Menata ulang taman kota, ruang rekreasi keluarga, ruang terbuka hijau kota sebagai tempat bertemu generasi muda dalam mengembangkan bakat dan minatnya.

\footnotetext{
${ }^{323}$ Lebih menekankan agama pada praktek hidup sehari-hari, bagaimana segenap umat beriman meleburkan diri dalam peristiwa hidup nyata, dengan itu pemahaman mengenai pentingnya keberadaan orang lain yang berbeda agama akan tercipta secara alamiah.
} 
Kelima, menciptakan suasana perjumpaan atau dialog informal. Bagaimana orang tanpa sadar meleburkan dirinya dalam keberagaman agama. Ini akan menciptakan suasana interaksi dan interelasi antara umat beragama secara alamiah, tanpa ada kecurigaan apapun. Pribadi-pribadi yang berdialog akan sangat santai dan hadir penuh kerendahan hati, suasana yang tentunya sangat dinamis. Pengakuan dan apresiasi pada sesama yang akan tercipta secara spontan. Spontanitas inilah yang melahirkan ketulusan dalam berdialog. Ini terwujud lewat dunia seni dan budaya, kegiatan-kegiatan yang asyik tanpa ada aspek formalitas sama sekali.

Kita selama ini lebih menyesakkan pemahaman agama hanya pada tataran ajaran yang mengarah pada abstraksi sekaligus mengabaikan pembiasaan pribadi untuk berinteraksi dalam mengeksplorasi imannya, imajinasi, hasrat, nalar, moralitas, kecerdasan emosional, serta spiritualitas keterlibatan dalam kehidupan sosial. Sebaliknya eksplorasi iman, moral, hasrat, spiritualitas keterlibatan harus menjadi konstruksi sosial yang hidup dan terbiasa sekaligus teralami dalam realitas sosial kemasyarakatan melalui perjumpaan yang berbentuk dialog agama dengan cara yang baru.

\section{Penutup}

Kita bangga sebagai bangsa yang sangat toleransi dalam hal pluralisme agama. Kita juga boleh berbangga atas terciptanya ruang dialog yang terbuka bagi keterlibatan agama-agama dalam menjalin kerjasama untuk kesekian kalinya. Semua seolah berjalan baik adanya. Namun beberapa persoalan keagamaan yang muncul belakangan ini, merasa cukup memberikan kesempatan kepada sesama agama untuk bisa merefleksikan kembali bagaimana seharusnya membangun ruang dialog keagamaan yang humanis ke depan.

Dialog antar agama belakangan mendapat tantangan yang serius, karena mengarah ke era persaingan antara hubungan antara agama-agama. Kita harus jujur bahwa era persaingan dalam dialog beragama ini berbahaya bagi kehidupan bersama sebagai bangsa, karena dipertautkan pada ruang ideologi politik. Dalam ruang ideologi politik itu dengan sendirinya akan menciptakan fundamentalisme agama dan fundamentalisme pasar. Keduanya bertemu untuk melanggengkan status kekuasaan tertentu dengan mengakomodir kepentingan kelompok tertentu saja. 
Karena itu jangan heran ketika menjelang pentas politik, pluralisme agama bisa dengan mudah diacak-acak oleh oknum yang tak bertanggung jawab. Ketika pemahaman agama direduksi hanya sebagai ideologi dan masuk dalam ideologi politik sebagai basis legitimasi maka dialog keagamaan sebagai mana terbingkai dalam dasar negara kita berada di postulat akhir sejarah. Bila situasi dialog di atas benar terjadi maka hubungan antara agama-agama di negara kita kembali bernostalgia ke masa kolonial. Masa ketika dialog bukan dari ketulusan, atau niat baik sebagai budaya nusantara, tetapi dialog yang munafik karena menyimpan banyak kepentingan.

Dialog masa kolonial selalu mendapat tantangan dari campur tangan kolonial yang lebih mengedepankan aspek 'doktriner' untuk memperoleh sebanyaknya pengikut serta kegiatan 'misioner' untuk memperoleh nilai ekonomi. Berikutnya, dialog masa kolonial lebih pada hubungan lembaga-lembaga keagamaannya serta terlibatnya kaum elit dari masing-masing agama, yang penuh siasat dengan berbagai kepentingan, sehingga dialog yang dibangun justru lebih mengarah pada situasi atau ruang yang dikondisikan.

Maka sebagai negara yang pluralisme dalam hal agama konsep dialog yang baik adalah membangun kerjasama antara agama dalam "semangat kemitraan." Perbedaan agama adalah "mitra kerjasama" dalam mewujudkan universalitas nilai-nilai kehidupan. Di tingkat pendidikan misalnya kita harus fokus pada pembelajaran mengenai sosiologi beragama. Yang mana memberi pemahaman kepada sesama tentang realitas perbedaan sebagai fakta penciptaan sang Khalik. Sebagai pemberian yang hakiki tanpa ada campur tangan manusia. Pendidikan agama harus menggiring setiap generasi beralih dari ajaran ke praktek hidup bersama. Harus secara langsung terjun ke dalam peristiwa hidup masyarakat. Sehingga setiap orang merasa terbiasa dengan perbedaan dan secara langsung teralami oleh realitas yang sudah jelas-jelas terbukti.

Seperti filsuf Perancis, Emmanuel Levinas merumuskan dengan sangat indah dalam konteks ini, yakni: 
"Hubungan tidak menetralisasi yang lain, tetapi memelihara yang lain. Yang lain sebagai yang berbeda bukan menjadi obyek yang menjadi milik kita atau menjadi kita, tetapi menarik diri dalam misterinya."324

Tentang Penulis:

Marz Wera - Menjabat Pengurus Pusat PMKRI 2018-2020. Founder komunitas Pelangi Nusantara, PENA Institut, dan MarzArtDeco studio. Menulis di Kompas, Pikiran Rakyat, Majalah Hidup, Sesawi.net, Geotimes dll. Penulis berkonsentrasi pada tema-tema dialog, resolusi konflik, teknokultur, dan komunikasi digital.

${ }^{324}$ Haryatmoko, 'Agama: Etika Mengatasi Kekerasan?,’' Kompas, 17 April 2000 